\title{
Organizational Politics and Work Outcomes: Moderating Role of Top Management Political Skills
}

\author{
IMRAN KHAN \\ MS Scholar, Institute of Business Studies and Leadership \\ Abdul Wali Khan University, Mardan \\ imranawkum001@gmail.com \\ SYED MOHSIN ALI SHAH \\ PhD Scholar, Birmingham City University, United Kingdom \\ Smas_kkhan@yahoo.com \\ DR. JEHANGIR \\ Assistant Professor, Institute of Business Studies and Leadership \\ Abdul Wali Khan University, Mardan \\ Jehangir@awkum.edu.pk
}

\begin{abstract}
This quantitative research was conducted to investigate the direct effects of Organizational Politics and moderating role of Top Management Political Skills on job outcomes such as Job Satisfaction and Employee Job Performance. The data was collected from 151 employees working in a private multinational tobacco manufacturing organization Phillip Morris Swabi Pakistan. Organizational Politics with others job outcomes were also studied in Pakistani context but the moderating effect of Political Skills needs to study for minimizing the negative consequences on employees and organizational goals. Self-administered questionnaire on 5-pointLikert scale was used for data collection. SPSS 21 was used for analysis and Descriptive Statistics, Pearson Correlation and Regression analysis were run for hypotheses testing. A letter was forwarded to IR manager for questionnaire filling assuring the confidentiality of the responses made by individuals and the reason choosing their organization for the study. The results revealed negative significant positive between Organizational Politics and Employee job performance and job satisfaction. The results also revealed that there is positive significant effect between the relationship of Organizational Politics and job outcomes i.e. Job Satisfaction and Employee Job Performance for the moderating role of Top Management Political Skills. Managerial implication and future research directions are suggested for further research.
\end{abstract}

Key Words: Political Skills, Organizational Politics, Job Performance, Job Satisfaction, Tobacco Pakistan.

\section{Introduction}

The importance and popularity of the political skill construct has accelerated with the realization and acceptance that organizations are political arenas (Mintzberg, 1983) in which individuals work to construct their desired realities through the creation and management of shared meaning (Ferris et al., 2007; Pfeffer, 1981, 2010). The prime aim of firm is to earn profit and share it with stakeholders. How it is done is based on the decisions of the management. Management needs to be vigilant and take such decision 
wherein the interests of all the stakeholders including employees are taken into account. They are in the business of capital and they have one law: the business of money to make money (Akbar, 2006). However, having said this, employees engage in different grouping for the sake of their own interests. A manager must know how to tackle such situation. These groupings are often referred to organizational politics. Thus, rather than assuming that organizational politics is automatically undesirable, practitioners and academics alike acknowledge that when used properly, organizational politics can serve as "another tool that employees and managers have for promoting goals that cannot be achieved in other ways" (Vigoda-Gadot \& Dryzin-Amit, 2006; Buchanan, 2008).

Organizational politics is an elusive type of power relationship in the workplace. It represents a unique domain of interpersonal relations, characterized by the direct or indirect engagement of people in influence tactics and power struggles. These activities are frequently aimed at securing or maximizing personal interests or, alternatively, avoiding negative outcomes within the organization (Ferris et al., 2002; Kacmar\& Ferris, 1991). However, they may also be targeted at securing or maximizing collective interests (team, group, organizational, or social) in cases where several decisions are possible that affect different interests. The number of studies on organizational politics has increased rapidly in recent decades. Vigoda-Gadot and Drory (2006) suggested that organizational politics is of prime importance to any type of organization in any field, market, sector, and culture. It has been studied from various perspectives, largely from a behaviorist point of view (e.g., Kipnis, Schmidt, \& Wilkinson, 1980) or a cognitive one (e.g., Ferris \&Kacmar, 1992). While many theoretical and empirical investigations have been undertaken, yet, it still requires a broad set of skills and knowledge of when to apply them. Politics is an inevitable part of organizations Therefore, for understanding of organizational politics phenomenon the concept of leadership is taken here in its generic influencing role. Same is the case for all the organizational situations because every situation requires political skill (e.g., Cropanzano, Howes, Grandey, \&Toth, 1997; Kacmar\& Ferris, 1991; Kipnis et al., 1980; Mayes Allen, 1977). Organizational politics has been considered almost synonymous with manipulation, coercive influence tactics, and other subversive and semi-legal actions (e.g., Ferris \& King, 1991; Mintzberg, 1983, 1985).

Research has shown that all organizations possess some degree of politics (Yang, 2009; Zhou \& Ferris, 1995; Pfeffer, 1992). Individuals in organizations often openly or secretly indulge in a variety of behaviors, actions or interpersonal relations for several purposes. The term organizational politics (OP) has been used to refer to a subjective reality (Ferris et al, 2002) which represents specific 'actions by individuals directed toward the goal of furthering their own self-interests without regard to the well-being of others or their organizations (Kacmar \& Baron, 1999). These actions are often neither enacted publicly, nor included in the formal rules and regulations of the organizations, nor explicitly prohibited (Farrell \& Peterson, 1982). At the heart of OP are actions such as selling ideas, influencing decision, increasing power, or achieving other targeted interests. at the expense of others (Brandon \&Seldman, 2004). Due to the pervasive nature of OP in organizations, an understanding of its impact will provide sound insight of this phenomenon and ultimately help promote organizational success. It may also help develop schemes or strategies that could impede the development of undesirable OP and foster desirable employee work outcomes, good organizational work climate and success, and ultimately contribute to society well-being as a whole.

2. Literature Review

\subsection{Organizational Politics and Job Outcomes}




\subsubsection{Organizational Politics and Job Satisfaction}

Power, influence and self-interest among employees have given birth to the notion of organization politics which have always been present in working environment of an organization in shape of striving over dearth resources, conflict during imperative decision making and the existence of varying interests among groups or individuals which as consequence have ignited the quest of power seeking, either inside or outside the boundaries of organization. When internal Politics exists in organization, the employees performance goes down and they cognitively plan not to remain in that organization. In such situation, all the energies and minds of those employees turn to other available job options. This basically cause decrease in job satisfaction (Bozeamn et al, 1996; Ferris et al, 1996). Employees not committed with the organization have negative attitude towards their jobs and organization. Such employees shows dissatisfaction towards their jobs and develop mistrust, disappointment while others do shows it positive. Such dissatisfied employees are expected of lower job outcomes (Vigoda, 2000). Chang et al, (2000)'s meta-analysis results indicated negative affect of Organizational Politics on individuals job satisfaction. Keeping in view these arguments, the following hypothesis is proposed.

\section{H1: Organizational Politics is negatively related to Job Satisfaction.}

\subsubsection{Organizational Politics and Employee Job Performance}

The most vital problem in a company is its Job Performance. This made researchers to research more and more (Shekrkon, 2001). They believe that performance is total expectation of organization from separate behavior samples of each person during specific period of time (Motowidlo, 2003). Job performance is a set of behavior which person show in relation to his job or, in other word, amount of efficiency gained due to the person job type (training, producing or servicing) (Rashidpoor, 2000). According to Hirschman (1970) theory of organizational politics, it was indicated that organizational politics has negative effects on employee job performance. When some of organizational member misuse politics. Every member of the organization is expected to perform well which in return benefits employees and organizational productivity. Based on previous studies the following hypothesis is developed.

H2: Organizational Politics is negatively related to Employee Job Performance.

\subsubsection{Political Skills and Job Outcomes}

Members of an organization experience some skills become their competitive edge in influencing others and can be used to cope up with different political situation. The capacity to understand people well and to influence them through personal competencies are basically the Political Skills which has a positive effect on employees behavior and attitude towards their jobs. Employees with high Political Skills can observe the activities of others. According to Ferris et al. (2005), Political Skills was linked with higher job performance. Based on this literature support it is argued that.

H3: Political Skills is positively related to Job Performance.

Politically Skilled individuals theorized to perceive themselves as master within their work environment and personally be secured (Ferris et al., 2011). In the overall work environment individuals predict negative and positiveassessments of these environment. Similarly, individuals with high political skills seems work as flexibleplatform for their own goal achievement (Ferris, Treadway et al., 2005; Ferris et al., 2007), which in turn effect attitudinal evaluations of job satisfaction (Locke, 1970). So far as Political Skills positively affect work attitude (Job Satisfaction), because politically skilled individuals use this mechanism to achieve their own goals and efforts are made in this regard. 
H4: Political Skill is positively related to Job Satisfaction.

\subsection{Political Skills moderate the relationship between Organizational Politics and Work Outcomes}

According to Ferris et al., (2005), Political Skill is the ability to understand others effectively and to use such knowledge to enhance one's personal or organizational objectives at the workplace. Political skills can be used positively in general because people having such skills are trustworthy and are thought to create feeling of trust, confidence and likeability. They can easily be adjusted with and cope up with the negative effects of even when there is high organizational politics exists. In many cases employees are not the solely responsible for their day to day work activities but the managers political skills effect their job attitude including their job satisfaction. Managers can play a vital role in the satisfaction level of its employees. We support the positive aspects of political skills within the organization on the basis of some previous studies of high level researchers in the same category. e.g. (Ahearn et al., 2004; Brouer et al., 2006; Ferris et al., 2007; Brouer et al., 2010). On the basis previous research, the following hypothesis is proposed.

\section{H5: Political Skills moderates the relationship between organizational politics and job}

satisfaction, such that the relationship will be stronger when political skill is high.

Politically skilled individuals have the ability to accurately view the work environment and read what motivates others in way that can benefits and can develop the work behaviors of employees. Organizations are considered as political in nature which cannot be eliminated from it but some of the unique skills of individuals could be utilized to challenge political situations and to cope up with its negative consequences. People high in political skills can read accurate picture of the organization, this basically leads them to understand what needs the employees to succeed. Further, it is much easy for them to make new connections and to build strong relationship within and outside the work environment (Perrewe et al., 2004; Treadway et al., 2004; Ferris et al., 2007; Brouer et al., 2010). These innovative working style of managers and top management make others comfortable with them. When majority of the employees working in such an environment where equality is maintained and performance is measured, it is argued that politically skilled individuals will able to use their knowledge and information in the organization to navigate the political environment.On the basis of this knowledge and information they are able to understand what performance is necessary and whether the performance of those employees is rewarded.

H6: Political Skills moderates the relationship between organizational Politics and Employee job performance, such that the relationship will be stronger when political skill

\subsection{Theoretical Framework} is high. 


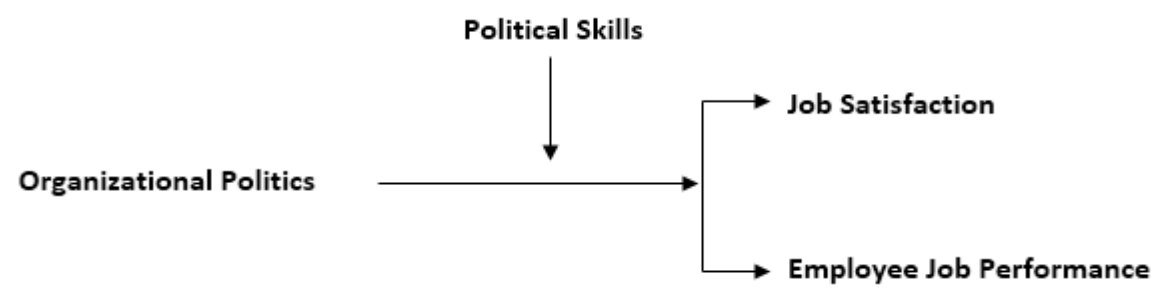

\section{Methodology}

\subsection{Data Collection and Sample Size}

This research paper consisted of employees working in a private sector tobacco company located on Mardan Swabi road at Bagicha Deheri. In this study the participants from different cadres were asked through questionnaire from a total of 133 employees, the responses made by the employees were 102. Most of the employees were male respondents while only 6 females were included in the survey. The IR manager were being asked through a request application about the survey at their department making them sure about the confidentiality and of the purpose of the study. Convenient sampling was used in conducting the survey. The questionnaire was distributed in English language and the participants were being facilitated with items included in the questionnaire. In this study Descriptive statistics, One-Way ANOVA and Pearson Correlations, Cronbach's Alpha (Reliability Analysis) and Multiple Regression Analysis were applied using SPSS 21.

\subsection{Measures}

\subsubsection{Political Skills}

Political Skills Inventory (PSI) Ferris, Treadway, Kolodinsky and Hochwarters' 2005." was used. A five likert point scale from 1. Strongly disagree to 5. Strongly Agree. Including items such as "Our Managers spend a lot of time and effort at work networking with others (NA).*, "Our Top Management understand people very well. (SA)"* and "Our Top Management is particularly good at sensing the motivations and hidden agendas of workers. (SA)"*. A total number of 16 items were taken from the PSI. Organizational Politics:

Gerald R Ferris, Organizational Politics Scale "Journal of Management 1992" Was used on 11 items questionnaire. To measure the construct five-pointLikert scale was used 1=Strongly Disagree 5=Strongly Agree including items such as "There is no place for yes-men in this industry: Good ideas are desired, even when it means disagreeing with superiors". (R) and "There has always been an influential group of employees in this industry that no one ever crosses". The Cronbach's Alpha was $\mathbf{0 . 9 6 8}$ for 09 items after deleting 2 items having less than .3 internal consistency.

\subsubsection{Job Satisfaction}

Gerald R Ferris, Organizational Politics Scale "Journal of Management 1992" Was used on a 13 items questionnaire. To measure the construct five point likert scale was used 1=Strongly Disagree 5=Strongly Agree including items such as "There is no place for yes-men in this industry: Good ideas are desired, even when it means disagreeing with superiors", (R) and "There has always been an influential group of employees in this industry that no one ever crosses". The Cronbach's Alpha was $\mathbf{0 . 9 6 8}$ 
for 11 items after deleting 2 items having less than . 3 internal consistency.

\section{Results}

Table 1. Correlations and Reliabilities

\begin{tabular}{|c|c|c|c|c|c|}
\hline & & 1 & 2 & 3 & 4 \\
\hline 1 & PS & $(0.968)$ & & & \\
\hline 2 & OP & 0.58 & $(0.767)$ & & \\
\hline 3 & JS & 0.493 & 0.266 & $(0.909)$ & \\
\hline 4 & EP & 0.793 & 0.15 & 0.853 & $(0.843)$ \\
\hline
\end{tabular}

The inter correlation table-1 given above shows no sign of multi-collinearity as all the independent variables are highly correlated. Additionally, the table also shows the reliability of the Cronbach's Alpha. The value of Cronbach's Alpha ranges from $(0.767$ to 0.968$)$. The value of Cronbach's Alpha for all the constructs are higher than the recommended value (.7), suggested by various researchers. (Hair et al., 2014; Saundaers et al., 2013; Kline, 2009).

Table 2.Results of Regression, Moderation Analysis

\begin{tabular}{llllllll}
\hline & \multicolumn{2}{l}{ Job Satisfaction } & & & \multicolumn{3}{c}{ Employee Job Performance } \\
\cline { 2 - 3 } \cline { 6 - 8 } & $\beta$ & $\mathrm{R} 2$ & $\Delta \mathrm{R} 2$ & & $\beta$ & $\mathrm{R} 2$ & $\Delta \mathrm{R} 2$ \\
\hline OP & -0.68 & 0.78 & & & -0.63 & 0.57 & \\
PS & 0.40 & 0.41 & & & 0.66 & 0.6 & \\
OP*PS & 0.58 & & 0.33 & & 0.06 & & 0.43 \\
\hline
\end{tabular}
Political Skills with work outcomes (Job Satisfaction and Employee Job Performance) with variance, change in variance and significant level to test our hypotheses. In this analysis we found that Organizational Politics is negatively affect Job satisfaction but it is statistically significant. While our Independent variable i.e. Organizational Politics is negatively related with Employee Job Performance but it is highly significant between Organizational Politics and Employee Performance (beta $=0.52, \mathrm{p}<0.01$ )

\section{Discussion}

Byrne (2005), suggested that the workplace Politics (Organizational Politics) is necessary for the normal functioning of any organization. "Buttering the negative effects becomes critical. The aim of the current study is to check the moderating role of top management political skills on the relationship between Organizational Politics and work outcomes (Job Satisfaction and Employee Job Performance) of a private sector organization of Pakistani context. The current study supports and is in line with the theory that every employee may not react the same to Organizational Politics as others, because of its relationship that may be different for various types of employees. The current study is much in line with the theoretical notions that were suggested by Ferris et al. (2002) and with other studies emphasizing the indirect nature of Organizational Politics-Outcomes relationship (e.g. Byrne, 2005; Harris et al., 2007; Hochwarter et al., 2003; Poon., 2004; 2006, Zivnaska et al., 2004).

Our study further contributes to the theory for the fit between the individual and the workplace. According to this theory of person-environment-organization Fit (POF; e.g., Bretz\& Judge, 1994; Chatman, 1989), the relationship between an individual and the 
organizational-social system has a strong impact on job outcomes and work outcomes for the individual and organizational level.

\subsection{Conclusion}

Politics within organizations is an evident and there is no organization which is safe from it and have not faced it, however based on conservation theory of Political skills it is revealed that managers of the organization can try to minimize the negative consequences of politics on job satisfaction and employee job performance by applying top management political skills. The main objective of the study was to check the moderating role of the Top Management Political skills on the relationship between Organizational Politics and work-related outcomes. The results concluded that the organizational politics is negatively related with work related outcomes, i.e. Job Satisfaction and Job performance but Top Management Political Skills reduce this negativity between organizational Politics and job satisfaction and employee job performance of the employees of the private sector manufacturing company. The association between job satisfaction and organizational politics is negativehowever,this association with Top Management Political Skills is correlated and is positively affect each otherand same is the case with employee job performance.

\subsection{Managerial Implications}

The top-level management and supervisors of the private sector organizations must concentrate on the fit between the employee/employer at the workplace so that the workers would better discuss, even minor issues with them relating to their work behavior they are facing difficulty in at the work place. The managers of the private sector organizations should focus on the talent and skills of constructive politics while hiring new employees; so, it would be a competitive edge for them to have more skilled and committed employees in their context. In the organizations managers are called to be one of the Key performance indicator for taking the organization to its peak in the market. A multinational organization should focus on politically skilled management. A manager having savvy of the Politics should focus on the negative aspects of the politics. Managers should identify issues which trigger the work environment even in the high level of the politics exist in the organization.

\subsection{Limitations and Future Research}

This study was limited to the moderating role of political skills in the link of organizational politics and job satisfaction and employee job performance. In organizations conflict management play vital role so we encourage future research to be carried the mediating role of political skills with conflict management styles of leaders. Personality of individuals are different so the moderating role of personality in the said relationship is also encouraged to check with other work outcomes like counter product behavior and turnover intension.

\section{References}

Andrews, M. C., Kacmar, K. M., \& Harris, K. J. (2009). Got political skill? The Impact of Justice on the Importance of Political Skill for Job Performance. Journal of Applied Psychology, 94(6), 1427.

Blickle, G., Ferris, G. R., Munyon, T. P., Momm, T., Zettler, I., Schneider, P. B., \& Buckley, M. R. (2011). A Multi-Source, Multi-Study Investigation of job Performance Prediction by Political Skill. Applied Psychology, 60(3), 449-474.

Blickle, G., Kramer, J., Schneider, P. B., Meurs, J. A., Ferris, G. R., Mierke, J., \&Momm, T. D. (2011). Role of Political Skill in Job Performance Prediction Beyond 
General Mental Ability and Personality in Cross-Sectional and Predictive Studies. Journal of Applied Social Psychology, 41(2), 488-514.

Dollinger, M. J., \& Golden, P. A. (1992). Interorganizational and collective strategies in small firms: Environmental effects and performance. Journal of management, 18(4), 695-715.

Ferris, G. R., \& Kacmar, K. M. (1992). Perceptions of organizational politics.Journal of management, 18(1), 93-116.

Ferris, G. R., Adams, G., Kolodinsky, R. W., Hochwarter, W. A., \& Ammeter, A. P. (2002). Perceptions of organizational politics: Theory and research directions. In The many faces of multi-level issues (pp. 179-254). Emerald Group Publishing Limited.

Ferris, G. R., Frink, D. D., Bhawuk, D. P., Zhou, J., \& Gilmore, D. C. (1996). Reactions of diverse groups to politics in the workplace. Journal of Management, 22(1), 2344.

Fliess, M., Lévine, J., Martin, P., \&Rouchon, P. (1995). Flatness and defect of non-linear systems: introductory theory and examples. International journal of control, 61(6), 1327-1361.

Gull, S., \& Zaidi, A. A. (2012). Impact of Organizational Politics on Employees' Job Satisfaction in the Health Sector of Lahore Pakistan. Interdisciplinary Journal of Contemporary Research in Business, 4(2), 156.

Harrison, J. S., Hitt, M. A., Hoskisson, R. E., \& Ireland, R. D. (1991). Synergies and post-acquisition performance: Differences versus similarities in resource allocations. Journal of Management, 17(1), 173-190.

Hochwarter, W. A., Witt, L. A., \&Kacmar, K. M. (2000). Perceptions of organizational Politics as a Moderator of the Relationship Between Consciousness and job Performance. Journal of Applied Psychology, 85(3), 472.

Huang, I. C., Chuang, C. H. J., \& Lin, H. C. (2003). The Role of Burnout in the Relationship between Perceptions off Organizational Politics and Turnover Intentions. Public Personnel Management, 32(4), 519-531.

Humborstad, S. I. W., \& Perry, C. (2011). Employee empowerment, job satisfaction and organizational commitment: An in-depth empirical investigation. Chinese Management Studies, 5(3), 325-344.

Humborstad, S. I. W., \& Perry, C. (2011). Employee empowerment, job satisfaction and organizational commitment: An in-depth empirical investigation. Chinese Management Studies, 5(3), 325-344.

Humborstad, S. I. W., \& Perry, C. (2011). Employee empowerment, job satisfaction and organizational commitment: An in-depth empirical investigation. Chinese Management Studies, 5(3), 325-344.

Imam, A., Shafique, M., \& Shah, F. T. (2014). Mediating Relationship of Job Satisfaction between Social Capital and Organizational Commitment in Employees: A Study of Banking Sector of Pakistan. Journal of Applied Environmental and Biological Sciences, 4(12), 274-283.

John, O. P., \& Srivastava, S. (1999). The Big Five trait taxonomy: History, measurement, and theoretical perspectives. Handbook of personality: Theory and research, 2(1999), 102-138.

Kacmar, K. M., \& Ferris, G. R. (1991). Perceptions of organizational politics scale (POPS): Development and construct validation. Educational and Psychological measurement, 51(1), 193-205.

Keohane, N. O. (2005). On Leadership. Perspectives on Politics, 3(4), 705-722. 
Kodisinghe, K. A. M. S. (2010). Impact of Perceived Organizational Politics on Employees' Job Satisfaction in the Commercial Banking SECTOR of Sri Lanka.

Miller, B. K., Rutherford, M. A., \&Kolodinsky, R. W. (2008). Perceptions of organizational politics: A meta-analysis of outcomes. Journal of Business and Psychology, 22(3), 209-222.

Molm, L. D. (1997). Coercive power in social exchange. Cambridge University Press.

Rokhman, W. (2010). The effect of Islamic work ethics on work outcomes. Electronic Journal of Business Ethics and Organization Studies.

Singh, K. (2012, April). Relationship bewteen organizational politics, job satisfaction and organizational commitment in UiTM Sarawak. In Business Engineering and Industrial Applications Colloquium (BEIAC), 2012 IEEE (pp. 377-382). IEEE.

Spector, P. E. (1997). Job satisfaction: Application, assessment, causes, and consequences (Vol. 3). Sage publications.

Thompson, J. R., \& Ingraham, P. W. (1996). The reinvention game. Public Administration Review, 291-298.

Valle, M., \& Witt, L. A. (2001). The moderating effect of teamwork perceptions on the organizational politics-job satisfaction relationship. The journal of social psychology, 141(3), 379-388.

Vigoda, E. (2000). Organizational politics, job attitudes, and work outcomes: Exploration and implications for the public sector. Journal of vocational Behavior, 57(3), 326-347.

Witt, L. A., Andrews, M. C., \&Kacmar, K. M. (2000). The Role of Participation in Decision-Making in the Organizational Politics-job Satisfaction Relationship. Human Relations, 53(3), 341-358. 